02 Royal Netherlands Institute for Sea Research

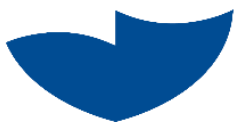

This is a postprint of:

van der Veer, H.W.; Cardoso, J.F.M.F.; Mateo, I.; Witte, J.IJ. \& van Duyl, F.C. (2018). Occurrence and life history characteristics of tropical flatfishes at the coral reefs of Curaçao, Dutch Caribbean. Journal of Sea Research, 142, 157166

Published version: https://dx.doi.org/10.1016/.j.seares.2018.09.010

Link NIOZ Repository: $\underline{\text { http://www.vliz.be/imis?module=ref\&refid=302058 }}$

[Article begins on next page]

The NIOZ Repository gives free access to the digital collection of the work of the Royal Netherlands Institute for Sea Research. This archive is managed according to the principles of the Open Access Movement, and the Open Archive Initiative. Each publication should be cited to its original source - please use the reference as presented.

When using parts of, or whole publications in your own work, permission from the author(s) or copyright holder(s) is always needed. 


\title{
Occurrence and life history characteristics of tropical flatfishes at the coral reefs of Curaçao, Dutch Caribbean
}

\author{
Henk W. van der Veer $^{1 *}$, Joana F.M.F. Cardoso ${ }^{1}$, Ivan Mateo ${ }^{23}$, Johannes IJ. Witte ${ }^{1}$,
} Fleur C. van Duyl ${ }^{4}$

${ }^{1}$ Royal Netherlands Institute for Sea Research, Department of Coastal Systems and Utrecht University; P.O. Box 59; 1790 AB Den Burg Texel; The Netherlands

${ }^{2}$ National Research Council Research Associateship Programs, 500 Fifth Street NW (Keck 568), Washington DC 20001

${ }^{3}$ present address: SAI Global Assurance Services LTD, Global Trust Certification LTD, Quayside Business Park, Mill Street, Dundalk, County Louth, Ireland

${ }^{4}$ Royal Netherlands Institute for Sea Research, Department of Marine Microbiology and Biogeochemistry and Utrecht University; P.O. Box 59; 1790 AB Den Burg Texel; The Netherlands

\section{ABSTRACT}

In this paper, life history characteristics of tropical flatfishes occurring at the fringing reefs of Curaçao to a depth of $20 \mathrm{~m}$ were studied. In total four flatfish species were caught, three common Bothidae species: the eyed flounder Bothus ocellatus, the mottled or maculated flounder B. maculiferus and the peacock flounder B. lunatus, and -in small numbers- the channel flounder Syacium micrurum. B. ocellatus and S. micrurum only occurred in sandy moats on the shallow reef terrace and fore reef and between coral patches on the terrace and fore reef slope. The other species could also be found on coral patches. The depth distribution of the various species overlapped: all species were caught over a depth range from a few meters up to $20 \mathrm{~m}$. All Bothus species were carnivores, preying on a variety of mobile benthic animals such as fishes and crustaceans. Reproduction seemed to occur year round in all three Bothus species. Growth between the species varied considerably with a maximum age found in $B$. maculiferus and $B$. lunatus of a little over 1 year, and in $B$. ocellatus of about 2 years. Growth was lowest in $B$. ocellatus and highest in $B$. lunatus: after one year $B$. ocellatus was about $10 \mathrm{~cm}$ in size, $B$. maculiferus $25 \mathrm{~cm}$ and $B$. lunatus about $35 \mathrm{~cm}$. After correction for differences in water temperature, the Bothus species showed a similar variability and range in growth rate as some temperate and subtropical flatfish species. These observations do not fit the hypothesis postulated by Pauly (1994) of an increasing importance of food-limitation in juvenile flatfish with decreasing latitude, despite the low densities and biomass of benthic 
in- and epifauna in the soft sediments in mangroves, seagrass beds and the reefs of Curaçao.

Keywords: coral reef, flatfish, life history, Bothus spec., Curaçao

*Corresponding author. E-mail address: henk.van.der.veer@nioz.nl

\section{Introduction}

Temperate coastal systems are often characterized by a substantial benthic community and especially for opportunistic (epi)benthic feeders such as juvenile (flat)fishes and crustaceans, food appear to be ample available (see for instance Beukema et al., 1996). Indeed, various juvenile flatfishes such as European plaice, flounder and sole, showed fast growth rates (Zijlstra et al., 1982; van der Veer 1986) and for a long time these rates were thought to represent the maximum possible rates under the prevailing temperature conditions, summarized by the 'maximum growth-optimal food condition hypothesis' (van der Veer \& Witte, 1993). However, on the other hand, growth variability within individuals and among groups was found in a variety of European coastal areas suggesting that in addition to food quantity also food quality is of importance (van der Veer \& Witte, 1993; Ciotti et al., 2013a,b, 2014). Even within various nursery areas, also seasonal variations in growth rate were observed, especially indications of some summer growth reduction (van der Veer et al., 2010, 2016; Freitas et al., 2012; Cardoso et al., 2016). A recent analysis also illustrated the importance of environmental variability (water temperature), non-genetic irreversible adaptation and especially sex in inducing variability in growth and hence in sizes (van der Veer et al., 2016). Overall, growth conditions in temperate flatfish species appear to be in the order of $0.5-1.0 \mathrm{~mm} \mathrm{~d}^{-1}$ and observations about stunted growth or starvation are lacking (for review see Ciotti et al., 2014).

It is thought that there is a general trend in food availability with low but relatively constant and uniform productivity at low latitude (Gross et al., 1988). The consideration that flatfishes in general might be overadapted to feeding on zoobenthic in- and epifauna led Pauly (1994) to the expectation that due to the decreasing importance of the benthic system towards the tropics, this would potentially result in increasing food limitation. So this would imply that reduced growth would become a more general phenomenon towards low latitudes and maybe year round in tropical systems. So far, this suggestion has not been studied and tested in more detail. Few laboratory studies (Reichert \& van der Veer, 1991) and field studies (van der Veer et al., 1994, 1995) on juvenile flatfish growth and Von Bertalanffy growth parameters for some commercial flatfish species (Pauly, 1994) both 
even suggest that growth rates of subtropical flatfishes on soft sediments can be of the same order (between $0.5-1.0 \mathrm{~mm} \mathrm{~d}^{-1}$ ) as that of temperate flatfish species.

Coral reef ecosystems are commonly found in tropical regions. Reef fish communities are composed of a variety of different taxa and species, often with complex life cycles, at least partly associated to the coral reef habitat (see for instance Sale, 2002). Among these reef fishes, also some flatfish species can be found, however, densities are often low, which might at least partly for epibenthic flatfish species due to the small amount of suitable habitat in the form of soft sediment (van Duyl, 1985). Apart from a general description of species composition and some information on feeding habits, ecological information about tropical flatfish species on coral reefs is scarce. Based on numerous studies in temperate and subtropical areas (a.o. Kuipers, 1977; Zijlstra, 1972), flatfish species are, except from seasonal migrations, in general considered as being rather sessile, especially during the juvenile stages. The condition and growth of these demersal species is often studied and considered to be an indicator for habitat quality of the benthic system (a.o. Ciotti et al., 2013ab, 2014; Freitas et al., 2016). However, it is unclear whether Pauly's hypothesis (Pauly, 1994) that tropical flatfishes are (year round) food limited is valid for these systems.

Often, various flatfish species occur in the same reef habitat with no basic information about their growth and reproduction, except for some observations about morphological differences. It is unclear to what extent the various species also differ in their performance despite occupying the same habitat. In this paper, basic population parameters such as abundance, distribution, length-weight, growth, reproductive effort etc. are collected for the common tropical flatfishes occurring on reefs environs in Curaçao, Dutch Caribbean, with the aim to estimate their growth and compare it with that in other systems. Some information is known about aspects of the social and reproductive behaviour of some flatfishes from a nearby island, Bonaire (Konstantinou \& Shen, 1995).

\section{Material and methods}

\subsection{Study area}

The study was performed on the fringing reef along the SW coast of Curaçao (Dutch Caribbean), situated between $12^{\circ} 02^{\prime}$ and $12^{\circ} 23^{\prime} \mathrm{N}$ and $68^{\circ} 12^{\prime}$ and $69^{\circ} 10^{\prime} \mathrm{W}$. At Curaçao there is a prevailing trade wind from the north-easterly direction. Therefore, the south, southwest and west coasts are more sheltered than the northeast coast (van Duyl, 1985). Water temperature at the reef varies annually around $27 \pm 1^{\circ} \mathrm{C}$.

The atlas of the living reefs of Curaçao and Bonaire (van Duyl, 1985) was used to select suitable shallow sand flats for sampling on the reef terrace. At one station, Porto 
Marie, a few flatfish were also caught at $20 \mathrm{~m}$ depth on a sand flat between the double reef. The dive sites are shown in Figure 1.

\subsection{Sampling}

Flatfishes were caught on sandy patches by scuba divers with nets. Two scuba divers swam next to each other carrying a small drift net of $270 \mathrm{~cm}$ in length, $75 \mathrm{~cm}$ in height and a mesh size of $1.25 * 1.25 \mathrm{~cm}$ with a tickler chain below the net and drifters on top. For small flatfish $(1-2 \mathrm{~cm})$ a small rectangular gauze net was used of $90 * 45 \mathrm{~cm}$ and a mesh size of $1.25 * 1.25 \mathrm{~cm}$ with underneath a lead rope. In order to spot and catch small fishes the sediment was disturbed softly and the rectangular gauze net was placed over a detected fish. Large flatfish were detected by swimming $0.5-1 \mathrm{~m}$ above the bottom, and were caught by circling and closing the net around them. Subsequently the flatfish was taken out of the enclosure by hand and stored in a bag.

All flatfish were kept in a bag with a mesh size of $0.5 * 0.5 \mathrm{~cm}$ (Underwater Kenetics ${ }^{\circledR}$ ) until the end of a dive. Fishes were put immediately on ice in a cooler, transported to the laboratory and stored individually in sealed plastic bags at $-7^{\circ} \mathrm{C}$ until further analyses within a week. A subsample was weighted before storing at $-7^{\circ} \mathrm{C}$ to determine weight loss due to freezing.

Flatfish were collected during the first two weeks of every month in 1995 and irregularly in 1996. Each day, two dives were made during daytime, randomly at various locations. On average, between 0 and 5 flatfishes were caught during each sampling dive on sandy patches on the reef. Diving continued until at least 20 specimens of each flatfish species were collected per monthly sampling period. In some months, fewer individuals were caught.

\subsection{Data analysis}

All analyses were done within a few days after collection of the fish. Before dissection, fish were defrosted in seawater. All flatfish were identified with the FAO sheets (FAO, 1978), Gutherz (1967) and Top \& Hoff Jr (1972). After species identification, standard length $(\mathrm{cm})$, total length $(\mathrm{cm})$ and wet weight $(\mathrm{g})$ was determined. Weight loss due to freezing was low between 1 and $2 \%$, therefore no correction was applied. Subsequently, the guts were removed and the gutted weight $(\mathrm{g})$ was measured. Stomach content was analysed and weighted if possible. Also gonads (>0.01 g) were weighted $(\mathrm{g})$.

Age was determined by removing from each individual the sagittae otoliths and preparing transverse thin sections of $400 \mu \mathrm{m}$ with a Buehler low-speed saw. Subsequently, each section was mounted on a microscope petrographic slide with thermoplastic glue and 
ground to the core in the sagittal plane with lapping film (30, 15, 9 and $3 \mu \mathrm{m})$. Otoliths were examined under an Olympus $M X-51$ transmitted light microscope at 400x at the National Marine Fisheries Services laboratory in Narragansett, Rhode Island, USA. Using Image-Pro image analysis software (Media Cybernetics 1998), increments were enumerated and increments widths along the anterior dorsal section of the otolith from the core to the outer edge following the standard protocol for reading and interpreting the otoliths (Searcy \& Sponaugle, 2000, 2001). For reading, first, all unclear, abnormally shaped (nonlinear growth axis) sagittae were discarded. A sagitta from each specimen was read randomly twice independently by the same reader. If the increment counts were within $5 \%$ of each other, one measurement was randomly selected for analysis (Searcy \& Sponaugle, 2000, 2001). If the increment counts differed by more than $5 \%$, the otolith was read again. If the increment counts from the third reading differed from the other readings by more than $5 \%$, the otolith was discarded. If the difference on the third count was less than $5 \%$ of one of the former readings, then one of these two measurements was randomly selected for analysis.

Growth curves were fitted to length-at-age data with the Von Bertalanffy growth model (VBGM) using the traditional version of the model developed by Von Bertalanffy with modifications by Beverton (1954) and Beverton \& Holt (1957) in Cailliet et al. (2006):

$$
\mathrm{L}_{\mathrm{t}}=\mathrm{L}_{\infty} \times\left(1-\mathrm{e}^{-\mathrm{K} \times\left(\mathrm{t}-\mathrm{t}_{0}\right)}\right)
$$

whereby $L_{\infty}$ is the estimated maximum total length $(\mathrm{cm}), K$ is the growth rate constant $\left(\mathrm{y}^{-}\right.$ $\left.{ }^{1}\right), t$ is age $(y), t_{0}$ is the age at length zero and $L_{t}$ is the observed length at age $t$.

The investment in total body, somatic and gonadal mass was analysed by means of the body mass index (BMI), the somatic mass index (SMI) and the gonadal mass index (GMI) which are defined respectively as

$$
\begin{array}{ll}
\mathrm{BMI}=1000 *\left(\text { Total mass } / \mathrm{TL}^{3}\right) & \left(\mathrm{g} \mathrm{cm}^{3}\right) \\
\mathrm{SMI}=1000 *\left(\text { Somatic mass } / \mathrm{TL}^{3}\right) & \left(\mathrm{g} \mathrm{cm}^{3}\right) \\
\mathrm{GMI}=1000 *\left(\text { Gonad mass } / \mathrm{TL}^{3}\right) & \left(\mathrm{g} \mathrm{cm}^{3}\right)
\end{array}
$$

whereby somatic mass was estimated as the gutted mass minus the gonad mass.

\subsection{Statistical analysis}

All data were stored in a database and all statistical analyses were performed in the R statistical package (R Development Core Team, 2018). Prior to the statistical analysis of the field data, a preliminary data exploration was carried out following the protocol described in Zuur et al. (2010). Potential outliers were checked using Cleveland dotplots, and multi-panel scatterplots using the xyplot function from the lattice package (Sarkar, 2008) were applied to identify the type of relationship (e.g. linear versus non-linear) 
between variables and the presence of collinearity. There was no collinearity between mass indices (BMI, SMI and GMI) and month or year for the three Bothus species (not shown).

The extent to which variability in total body, soma and gonad condition was accounted for by seasonal variability among each area was examined by fitting generalized additive models (GAMs) with Gaussian distribution errors. Two models were used:

Model 1: Mass index $\mathrm{i}=\mathrm{a}+f\left(\right.$ month $\left._{\mathrm{i}}\right)+\epsilon_{\mathrm{i}}$

Model 2: Mass index $i=a+f\left(\right.$ month $\left._{i}\right)+$ factor $\left(\operatorname{sex}_{i}\right)+\epsilon_{i}$ where $a$ is an intercept, $f$ is the smoothing function and $\epsilon_{i}$ is the residual. Model 1 assumed that males and females had the same monthly trend in mass index while Model 2 assumed that there were different trends between males and females. Differences in BMI, SMI and GMI between sexes were analysed by comparing the two models in terms of the Akaike Information Criterion (AIC), whereby the best model is the one with the lowest AIC.

In order to obtain normality, GMI data were transformed using the squared root transformation. Due to the fact that individuals with no gonadal development $(<0.01 \mathrm{~g})$ were present the whole year and normality could not be obtained even after transformation, the gonad data were analysed in two ways: analysis of individuals with gonadal development (zeroes excluded) after squared root transformation (Gaussian distribution) and analysis of the presence and absence of gonadal development. For the last, the response variable (rank difference) was coded as a value from 0 to 1 ; therefore, a Gaussian distribution could not be used and instead a binomial distribution with a logistic link function was taken.

GAMs were developed and tested using the mgcv package (Wood, 2011) and Von Bertalanffy growth curves were analysed using the FSA and the nlstools packages (Baty et al., 2015; Ogle, 2017).

\section{Results}

\subsection{Species composition}

In total four flatfish species were caught. On the sandy moats between the coastline and the coral reef and on sandy patches in between the reef corals, three Bothidae species were found: the eyed flounder Bothus ocellatus, the mottled flounder B. maculiferus and the peacock flounder $B$. lunatus. $B$. maculiferus and $B$. lunatus could be distinguished by the dorsal profile of the head: $B$. lunatus has a notch above the nostril, while the dorsal profile of the head of $B$. maculiferus is not notched. Also the number of pectoral fin rays differs: between 9 (B. lunatus) and 11 (B. maculiferus). The eyed flounder and the mottled flounder could be distinguished by the blue spots of the mottled flounder. Male mottled flounder also had an extended pectoral fin almost reaching the base of the causal fin. Eyed 
flounders were smaller than mottled flounders, respectively $15 \mathrm{~cm}$ total length (TL) and 30 cm TL (Bohnsack \& Harper, 1988).

The fourth species caught at the sand flats on the lower terrace near the drop off was the channel flounder Syacium micrurum. The channel flounder also belongs to the family of the Bothidae but it has an elongated body and lacks ocellated spots compared with the three other Bothidae species that were found. The channel flounder was also better camouflaged or covered with sand. Since only 12 individuals in size between 10 and $22 \mathrm{~cm}$ TL were caught, the species was excluded from further analysis.

\subsection{Distribution}

All three flounder species occurred on the sandy flat patches in between patch reefs and the occurrence of the eyed flounder Bothus ocellatus was restricted to these areas. $B$. ocellatus was always found on top of the sediment or even slightly buried. The two other species, the mottled flounder $B$. maculiferus and the peacock flounder $B$. lunatus were also found lying flat on top of the sediment but also sometimes curved upwards as if "sunbathing". These two species were incidentally also found lying curved upwards on top of hard substrates.

The three flounder species differed with respect to the size range caught (Fig. 2). $B$. ocellatus was caught from 2 to $14 \mathrm{~cm} \mathrm{TL}$, for $B$. maculiferus the size caught ranged from 2 to $26 \mathrm{~cm}$ and for $B$. lunatus no small specimens and only large individuals from $15 \mathrm{~cm}$ to $37 \mathrm{~cm}$ were caught.

The depth distribution of the various species overlapped (Fig. 3). B. ocellatus was caught over a depth range from $1 \mathrm{~m}$ up to $20 \mathrm{~m}$ (max. dive depth) and did not show a relationship between water depth and fish size. Also the two other species, $B$. maculiferus and $B$. lunatus, were found over the whole diving depth range from shallow waters to 20 $\mathrm{m}$, whereby at least in $B$. maculiferus, there was a tendency of a positive relationship between fish size and water depth. For $B$. lunatus numbers caught were too low for such an analysis.

\subsection{Feeding}

All small Bothus species $<5 \mathrm{~cm}$ mainly consumed copepods (Fig. 4). With increasing size up to $10-15 \mathrm{~cm}$ the contribution of copepods decreased and $B$. ocellatus shifted to shrimps, crabs and fishes (Fig. 4).

B. maculiferus $>5 \mathrm{~cm}$ predated on shrimps, crabs and small fishes up to $4 \mathrm{~cm}$, and with increasing fish size, the contribution of fishes increased (Fig. 4). One individual contained a full gut of fish larvae, a juvenile moray and a snake-eel. Another flatfish was 
observed foraging close to a school of yellow goat fish (Mulloidichthys martinicus) which disturbed the sand.

For $B$. lunatus, not enough fish with stomach contents were present to allow a detailed analysis for all size classes. The stomach content of $B$. lunatus $>5 \mathrm{~cm}$ comprised of crabs and mainly small fishes. Larger flatfish also consumed some small Cephalopods.

In all species, throughout the year, stomach content did not differ.

\subsection{Age and growth}

No significant differences in length-weight relationships were found between sexes (not shown), so data were treated together. Total length - total wet weight relationships in the form of $\mathrm{W}=\mathrm{aL}^{3}$, showed all species with similar relationships for Bothus maculiferus and $B$. lunatus $(a=0.012)$ with a slightly higher value for $B$. ocellatus $(a=0.013)$ (Fig. $5)$.

Age and growth between the three species varied considerably despite the similarity in body shape. Otolith reading indicated that the maximum age found for $B$. maculiferus and B. lunatus was slightly over 1 year, and for B. ocellatus around 2 years (Fig. 6). Growth was lowest in B. ocellatus and highest in B. lunatus: after one year B. ocellatus was about $10 \mathrm{~cm}$ in size, B. maculiferus $25 \mathrm{~cm}$ and B. lunatus about $35 \mathrm{~cm}$ (Fig. 6). Von Bertalanffy growth parameters differed between species (Table 1), however the estimates were based on scattered data and at least for $B$. maculiferus the estimate was unreliable due to the absence of large individuals in the samples.

For all species, body mass index (BMI) and somatic mass index (SMI) did not differ between males and females (similar AIC between models with and without separate sexes), therefore they were combined for further analysis. Significant differences in BMI and SMI along the year were found for both B. ocellatus and B. maculiferus (GAM; B. ocellatus: BMI $\mathrm{F}=4.17, \mathrm{p}<0.01$ and SMI $\mathrm{F}=4.84, \mathrm{p}<0.01 ; B$. maculiferus: $\mathrm{BMI} F=7.71, \mathrm{p}<0.01$ and $\mathrm{SMI}$ $\mathrm{F}=8.23, \mathrm{p}<0.01)$. For $B$. lunatus no differences in BMI and SMI were found along the year (GAM; BMI $F=0.50, p=0.48$; SMI $F=0.69, p=0.41$ ) which could be due to the low number of observations in some months (Fig. 7). For B. ocellatus, highest values were found around June-July and for $B$. maculiferus highest values were found at the end of the year.

\subsection{Reproductive effort}

Gonadal mass ( $>0.01 \mathrm{~g}$ ) was found from a size of about $5 \mathrm{~cm}$ in $B$. ocellatus, 10 $\mathrm{cm}$ in B. maculiferus and $10-15 \mathrm{~cm}$ in B. lunatus (not shown). Differences in GMI between sexes showed that GMI significantly differed between males and females in $B$. ocellatus and $B$. lunatus (lowest AIC for the model including the factor sex), while in $B$. maculiferus 
differences between sexes were very small (similar AIC between models with and without the factor sexes). Therefore, GMI was treated separately between sexes in further analysis. In $B$. ocellatus, both females and males showed no significant differences in GMI along the year (GAM; females $F=1.12, p=0.31$; males $F=0.75, p=0.46$ ) (Fig. 8). This means that in both females and males there was no pattern during the course of the year but the absolute mean values differed with females showing a larger investment. In contrast, females of $B$. maculiferus showed significant differences in GMI along the year (GAM; $F=3.73, p<0.05$ ) suggesting low values in January/February which increase until about July, whereas males did not show differences along the year ( $G A M ; F=2.26, p=0.10)$. For female $B$. Iunatus no model prediction was possible due to the small number of individuals in some months. In males, the pattern in GMI along the year showed a borderline significant difference (GAM; $F=2.09, p=0.04$ ) with higher values around June and lower values in the beginning of the year. However, several months had only 1 observation, which could have influenced model results.

Seasonal patterns in reproductive effort can also be illustrated by estimating the proportion of fishes with gonads (weight $>0.01 \mathrm{~g}$ ) present over time (Fig. 9). No significant differences between sexes were found for the different species (similar AIC between models with and without separate sexes). In all species, no significant difference in the presence of gonads (weight $>0.01 \mathrm{~g}$ ) was found along the year (GAM, B. ocellatus: $X^{2}=0$, $\mathrm{p}=0.99 ; B$. maculiferus: $X^{2}=14.04, \mathrm{p}=0.08 ; B$. lunatus: $X^{2}=5.97, p=0.13$ ) (Fig. 9).

\section{Discussion}

\subsection{Sampling and identification}

The relatively low abundance of flatfishes as found in this study compared with other fish species in the area (Nagelkerken et al., 2000) makes the collection of the flatfishes at the fringing reefs of Curaçao demanding and time consuming. Also the taxonomic identification of these tropical flatfish species is difficult (Evseenko, 2008; Emery, 2016). In the beginning of this programme, only two Bothus species were identified: $B$. ocellatus and $B$. lunatus. However, after a few months it became clear from differences in the profile of the head and the number of pectoral fin rays, that $B$. Iunatus consisted of a mixture of $B$. maculifereus and B. lunatus (van der Geest \& Langevoort, 1995). Also the identification of $B$. ocellatus and $B$. robinsi was problematic at that time (FAO, 1978; Gutherz, 1967; Top \& Hoff Jr, 1972) and still is (Carpenter, 2005; Richards, 2005; Evseenko, 2008; Emery, 2016). In Brasil, fisherman do not differentiate between these species and use the same generic name for both (Begossi et al., 2016). Based on dorsal, anal and pectoral fin ray counts a combination with the number of gillrakers, and 
the absence of two large dark spots on the caudal fin (Jutare, 1962) all individuals were identified as $B$. ocellatus. However, species verification by means of molecular techniques (DNA barcoding) would be useful (Weigt et al., 2012).

\subsection{Life cycle}

The life cycle of these Bothus species resembles that of other flatfish species: pelagic egg and larval stages followed by metamorphoses and a settlement into the demersal phase. This means that patchy populations on the isolated fringing reefs such as in the Caribbean are only connected by migration during the egg and larval stages. No information is available about egg and larval development time. The larvae of the different species appear to be very similar morphologically and their almost pigment-free body makes them almost invisible in the water column (Evseenko, 2008). All species are considered to belong to the nerito-oceanic group (according to Parin, 1968 in Evseenko, 2008) with a long pelagic development phase. As a consequence, Bothus larvae are widely distributed in the northern waters. This implies that they most likely will belong to a larger panmictic population with no clear structure (cf. Doherty \& McB. Williams, 1988).

With increasing size, flatfish are found in deeper waters, especially in the case of $B$. maculiferus and $B$. lunatus. In $B$. maculiferus, it seems that the largest individuals were missed, maybe because they occur in waters deeper than $20 \mathrm{~m}$ (the max. dive depth). Most $B$. ocellatus were caught in shallow waters, buried in sandy patches, while the other species were more abundant on the sandy shallow terrace as well as the fore reef slope.

\subsection{Seasonal patterns}

The gonadal mass index does not show a clear seasonal pattern in reproduction for the three Bothus species, although in $B$. maculiferus and $B$. lunatus higher values seem to occur around July and low values in the beginning of the year. Jutare (1962) also observed an almost year-round spawning in $B$. ocellatus around Florida. Overall, this suggests some differences between species with a sequence in reproduction of $B$. ocellatus, followed by $B$. maculiferus and $B$. Iunatus. However, more data are required to fully understand the reproductive cycle of these species, especially information about the seasonal pattern of the various egg development stages in mature adults. It is known that in $B$. ocellatus, mating occurs in groups, each consisting of a male and more females, whereby each female also has a distinct subunit within the male's territory (Konstantinou \& Shen, 1995).

In contrast to the patterns in reproduction, significant although small seasonal differences in body mass and somatic mass index were found along the year in $B$. ocellatus and $B$. maculiferus, but not in $B$. lunatus. It is unclear whether these differences also occur 
in body composition. For $B$. ocellatus and $B$. maculiferus the observed maximum size in this study was larger than described in Fishbase (www.fishbase.org).

The lack of a clear seasonal pattern in reproduction also implies the absence of any pattern in settlement. For $B$. ocellatus, pigmented larvae were found from $17 \mathrm{~mm}$ onwards (Jutare, 1962), suggesting settlement around this size. For the other species, information is lacking, but settlement will be in the same size range. The size distribution of the individuals caught in the present study indicates that sampling was effective in collecting just-settled individuals, at least for $B$. ocellatus and $B$. maculiferus. However, for $B$. lunatus the smallest individual caught was $15 \mathrm{~cm}$. For this species, either juveniles were overlooked or settlement occurred outside the sampling area: several small flatfishes have been observed with submarines (CuraSub) at Curaçao on sandy slopes below the reef $>50 \mathrm{~m}$ depth (van Duyl, pers. obs.). Juveniles of $B$. ocellatus and B. maculiferus were especially found in shallow areas. Under the assumption that age was determined correctly the maximum age found of $B$. maculiferus and $B$. lunatus was at least a little over 1 year, and for $B$. ocellatus around 2 years. This means that the population structure of the various Bothus species will consist of only a few age classes.

\subsection{Trophic status}

Bothus species are considered to be generalized carnivores, preying on a variety of mobile benthic animals such as crustaceans, worms, and small fishes (Randell, 1967, 1996). Stomach content analysis done in this study supports this view. Based on these prey items the trophic status of the studied Bothus species ranks from 3.7 in $B$. maculiferus, 3.8 in B. ocellatus to 4.5 in B. lunatus (www.fishbase.org). Bothus species can be considered as predators on reef systems focussing on relatively small epifaunal prey items. The low biomass of benthic infauna in the soft sediments at the reefs of Curaçao of around $0.2 \mathrm{~g} \mathrm{AFDW} \mathrm{m}^{-2}$ (Bremer, 1997) illustrates that these soft bottom sediments can only provide shelter but not food for these species and also that there is only a niche for epibenthic feeding carnivores such as Bothus species.

\subsection{Are tropical flatfishes (year round) food limited?}

Growth of the various species was analysed by counting otolith increments, under the assumption that these rings were deposited daily and that size-selective processes do not seriously bias the observations (Searcy \& Sponaugle, 2000; 2001). The analysis suggested that growth between the three species varied considerably whereby growth was lowest in B. ocellatus and similar in the other two species. 
An analysis of growth rates of juvenile flatfishes in relation to latitude require a general framework based on first principles in which the quantitative aspects of energy location in relation to temperature and food conditions are described in a coherent way. The theory of dynamic energy budgets (DEB) developed by Kooijman (1993, 2000) offers such a framework: differences between species can be captured in the same model using a different set of parameter values only (Kooijman, 2000; van der Veer et al., 2006). The problem is that so far parameter estimates are lacking for tropical flatfishes (https://www.bio.vu.nl/thb/deb/deblab/add my pet/species list.html).

For all three species the length -weight relationship could be described by the "cube law" ( $b=3)$ (Ricker, 1973). This means that the body form maintains a constant proportion to the length and the fish grows isometrically. Furthermore, length-weight relationships were almost identical for the three Bothus species $(a=0.012-0.013)$. With almost identical shapes, this means from an energetic point of view, that the physiology (such as maintenance) of the various related Bothus species most likely will also correspond (Kooijman, 2000; van der Veer et al., 2006). According to the Dynamic energy budget theory (Kooijman, 1993, 2000), differences in growth will result in either differences in the so-called Kappa parameter describing the energy participation between growth and reproduction and/or in the food ingestion rate. The GSI is an indication for Kappa (van der Veer et al., 2001; 2006). Maximum values for the three Bothus species were around 0.4 suggesting no large differences in Kappa. Differences in food ingestion rate might be more likely since the maximum stomach content found, expressed as stomach mass index (=stomach weight/somatic weight), was larger in $B$. maculiferus $(0.188)$ than in $B$. ocellatus (0.109). Unfortunalely, for $B$. lunatus not enough data were present.

An indirect approach is the estimate of growth based on length increase of the population during the juvenile stage. A preliminary comparison of the seasonal patterns in mean length of some juvenile temperate, subtropical and tropical flatfish species suggested a large variability in population growth (van der Veer et al., 1994). After correction for the differences in water temperature (assuming a $\mathrm{Q}_{10}$ of 2), there is no relationship between growth and latitude (Table 2). The Bothus species of this study fit with these observations: a large variability among species but no differences in growth range with temperate and subtropical species. The observed variability will partly be caused by environmental (a)biotic variability (temperature, food conditions) and by the fact that the various flatfishes show a taxonomic distinctness with different food preferences and maybe also physiological performance. Nevertheless, these observations do not support the hypothesis postulated by Pauly (1994) of an increasing importance of food-limitation in juvenile flatfish with decreasing latitude, despite the low densities and biomass of benthic in- and epifauna 
in the soft sediments in mangroves, seagrass beds and at the reefs of Curaçao (Bremer, 1997, Nagelkerken, 2000).

\section{Acknowledgements}

Data were collected during various student internships at Carmabi, Curaçao (van der Geest \& Langevoord, 1995; Hoetmer \& Schrier, 1996; Bremer, 1997). Thanks are due to Carmabi for offering field and laboratory facilities and to (in alphabetic order) Ewout Adriaans, Simone Bremer, Martin Hoetner, Martin Langevoord, Harm G. van der Geest and Arjan Schrier for their field work and analysis of the samples.

\section{References}

Baty, F., Ritz, C., Charles, S., Brutsche, M., Flandrois, J.-P., Delignette-Muller, M.-L., 2015. A Toolbox for Nonlinear Regression in R: The Package nlstools. J. Stat. Softw. 66, 121.

Bohnsack, J.A., Harper, D.E., 1988. Length-weight relationships of selected marine reef fishes from the southeastern United States and The Caribbean. NOAA Tech. Mem. NMFS-SEFC-215, $31 \mathrm{pp}$.

Begossi, A., Salivonchyk, S., Lopes, P.F.M., Silvano, R.A.M., 2016. Fishers' knowledge on the coast of Brazil. J. Ethnobiol. Ethnomed. 12, 20.

Beukema, J.J., Essink, K., Michaelis, H., 1996. The geographic scale of synchronized fluctuation patterns in zoobenthos populations as a key to underlying factors: climatic or man-induced. ICES J. Mar. Sci. 53, 964-971.

Beverton R.J.H., 1954. Notes on the use of theoretical models in the study of the dynamics of exploited populations, U.S. Fish. Lab. Beaufort, N.C., Misc Contrib 2.

Beverton R.J., Holt S.J., 1957. On the dynamics of exploited fish populations. U.K. Min. Agric. Fish., Fish. Invest. (Ser. 2) 19, 1-533.

Bremer, S., 1997. Temporal and spatial patterns in the soft-bottom communities along the coasts of Curaçao, Netherlands Antilles. NIOZ-rapport 1997-2, 27 pp.

Cailliet, G.M., Smith, W.D., Mollet, H.F. Goldman, K.J., 2006. Age and growth studies of chondrichthyan fishes: the need for consistency in terminology, verification, validation, and growth function fitting. Environ. Biol. Fish. 77, 211.

Cardoso, J.F.M.F., Freitas, V., de Paoli, H., Witte, J.IJ., van der Veer, H.W., 2016. Growth conditions of 0-group plaice Pleuronectes platessa in the western Wadden Sea as revealed by otolith microstructure analysis. J Sea Res. 111, 88-96

Ciotti, B.J., Targett, T.E., Burrows, M.T., 2013a. Spatial variation in growth rate of early juvenile European plaice Pleuronectes platessa. Mar. Ecol. Prog. Ser. 475, 213-232. 
Ciotti, B.J., Targett, T.E., Burrows, M.T., 2013b. Decline in growth rates of juvenile European plaice (Pleuronectes platessa) during summer at nursery beaches along the West Coast of Scotland. Can. J. Fish. Aquat. Sci. 70, 720-734.

Ciotti, B.J., Targett, T.E., Nash, R.D., Geffen, A.J., 2014. Growth dynamics of European plaice Pleuronectes platessa L. in nursery areas: a review. J. Sea Res. 90, 64-82.

Dawson C.E., 1968. Contributions to the biology of the Maxican flounder, Cyclopsetta chittendeni in the Northern Gulf of Mexico, Trans. Am. Fish. Soc, 97, 504-507.

Doherty, P.J., McB Williams, D., 1988. The replenishment of coral reef fish populations. Oceanogr. Mar. Biol. Annu. Rev. 26, 487-551.

Emery, M.K., 2016. Taxonomic revision of the genus Bothus (Bothidae; Pleuronectiformes). Master Thesis, Ottawa-Carleton Institute of Biology, University of Ottawa.

Evseenko, S.A., 2008. Distribution and routes of drift migrations in larvae of three species of flatfish Bothus (Bothidae) in open waters of the Northern Atlantic. J. Ichtyology 48, 792-809.

FAO, 1978. FAO species identification sheets for fishery purposes, Vol 1. Fisher W (ed), Rome.

Freitas, V., Kooijman, S.A.L.M., van der Veer, H.W., 2012. Latitudinal trends in nursery quality of temperate coastal areas for juvenile flatfish. Mar. Ecol. Prog. Ser. 471, 203214.

Freitas, V., Witte, J.IJ., Tulp, I., van der Veer, H.W., 2016. Subtidal areas replacing intertidal flats as the main nursery habitat for plaice Pleuronectes platessa $\mathrm{L}$. in the western Wadden Sea. J. Sea Res. 111, 65-75.

Gross, M.R., Coleman, R.M., McDowall, R.M., 1988. Aquatic productivity and the evolution of diadromous fish migration. Science 239, 1291-1293.

Gutherz, E.J., 1967. Field guide to the flatfishes of the family Bothidae in the Western North Atlantic. United States Department of the Interior. Fish and Wildlife Service. Bureau of Commercial Fisheries. Circular 263, 47 pp.

Hoetmer, M., Schrier, A.J., 1996. The flatfish population around Curaçao, Netherlands Antilles. NIOZ-rapport, unpubl., $30 \mathrm{pp}$.

Jutare, T.V., 1962. Studies on the biology of Bothus ocellatus with a description of a related new species. Master thesis, Univ. Miami, $97 \mathrm{pp}$.

Carpenter, K.E. (ed.), 2002. The living marine resources of the Western Central Atlantic. Volume 3: Bony fishes part 2 (Opistognathidae to Molidae), sea turtles and marine mammals. FAO Species Identification Guide for Fishery Purposes and American Society of Ichthyologists and Herpetologists Special Publication No. 5. FAO, Rome, 1375-2127.

Kooijman, S.A.L.M., 1993. Dynamic energy budgets in biological systems. Theory and applications in ecotoxicology. Cambridge, UK: Cambridge University Press. 
Kooijman, S.A.L.M., 2000. Dynamic energy and mass budgets in biological systems. Cambridge, UK: Cambridge University Press.

Konstantinou, H., Shen, D.C., 1995. The social and reproductive behaviour of the eyed flounder, Bothus ocellatus, with notes on the spawning of Bothus lunatus and Bothus ellipticus. Environm. Biol. Fishes 44, 311-324.

Kuipers, B.R., 1977. On the ecology of juvenile plaice on a tidal flat in the Wadden Sea. Neth. J. Sea Res. 11, 56-91.

Nagelkerken, I.A., 2000. Chapter 8, General discussion. In: Importance of shallow-water bay biotopes as nurseries for Caribbean reef fishes. PhD thesis, University of Nijmegen, The Netherlands. 168 pages. ISBN 90-6464035-1

Nagelkerken, I., van der Velde, G., Gorissen, M.W., Meijer, G.J., van 't Hof, T., den Hartog, C., 2000. Importance of mangroves, seagrass beds and the shallow coral reef as a nursery for important coral reef fishes, using a visual census technique Estrua. Coast. Shelf Sci 51, 31-44.

Ogle, D.H., 2017. FSA: Fisheries Stock Analysis. R package version 0.8.17.

Parin N.V., 1968. Ichthyofauna of the Oceanic Epipelagial, Nauka, Moscow [in Russian].

Pauly, D., 1994. A framework for latitudinal comparisons of flatfish recruitment. Neth. J. Sea Res. 32, 107-118.

R Development Core Team, 2018. R: A Language and Environment for Statistical Computing. $\mathrm{R}$ Foundation for Statistical Computing, Vienna, Austria (URL http://www.R-project.org).

Randall, J.E., 1967. Food habits of reef fishes of the West Indies. Studies Trop. Oceanogr. $5,665-847$.

Randell, J.E. 1996. Caribbean reef fishes. 3rd edition. T.F.H. Publications, Inc. Ltd. Hongkong 368 pp.

Reichert, M.J.M., van der Veer, H.W., 1991. Settlement, abundance, growth and mortality of juvenile flatfish in a subtropical tidal estuary (Georgia, U.S.A.). Neth. J. Sea Res. $27,375-391$.

Richards, W.J., 2005. Early stages of Atlantic fishes: An identification guide for the Western Central North Atlantic, Two volume set, CRC Press, Boca Raton, 1312 pp

Ricker, W.E., 1973. Linear regressions in fishery research. J. Fish. Res. Bd Can. 30, 409434.

Sale, P.F., 2002. Coral reef fishes. Dynamics and diversity in a complex ecosystem. Acad Press, Amsterdam, 549 pp.

Sarkar, D., 2008. Lattice: Multivariate data visualization with R. Springer, New York. ISBN 978-0-387-75968-5.

Searcy, S.P., Sponaugle, S., 2000. Variable larval growth in a coral reef fish. Mar. Ecol. Prog. Ser. 206, 213-226. 
Searcy, S.P., Sponaugle, S., 2001. Selective mortality during the larval juvenile transition in two coral reef fishes. Ecology 82, 2452-2470.

Top, R.W., Hoff Jr, F.H., 1972. Flatfishes (Pleuronectiformes). Florida Marine Resources Institute, Dept. Nat. Resources., Mem. Hourglass Cruises. 4, 135 pp.

van der Geest, H.G., Langevoord, M., 1995. Ecological observations on flatfish on the reefs and inner bays around Curaçao, Netherlands Antilles. NIOZ-rapport 1995-9, 59 pp.

van der Veer, H.W., 1986. Immigration, settlement and density-dependent mortality of a larval and early post-larval 0-group plaice (Pleuronectes platessa) population in the western Dutch Wadden Sea. Mar. Ecol. Prog. Ser. 29, 223-236.

van der Veer, H.W., Berghahn, R., Rijnsdorp, A.D., 1994. Impact of juvenile growth on recruitment in flatfish. Neth. J. Sea Res. 32, 153-173.

van der Veer, H.W., Cardoso, J.F.M.F., van der Meer, J., 2006. Estimation of DEB parameters for various North Atlantic bivalve species. J. Sea Res. 56, 107-124.

van der Veer, H.W., Freitas, V., Koot, J., Witte, J.IJ., Zuur, A.F., 2010. Food limitation in epibenthic species in temperate intertidal systems in summer: analysis of 0-group plaice Pleuronectes platessa. Mar. Ecol. Prog. Ser. 416, 215-227.

van der Veer, H.W., Jung, A.S., Freitas, V., Philippart, C.J.M., Witte, J.IJ., 2016. Possible causes for growth variability and summer growth reduction in juvenile plaice Pleuronectes platessa L. in the western Dutch Wadden Sea. J. Sea Res. 111, 97-106. van der Veer, H.W., Kooijman, S.A.L.M., van der Meer, J., 2001. Intra- and interspecies comparison of energy flow in North Atlantic flatfish species by means of dynamic energy budgets. J Sea Res. 45, 303-320.

van der Veer, H.W., Witte, J.IJ., 1993. The 'maximum growth/optimal food condition' hypothesis, a test for 0-group plaice Pleuronectes platessa in the Dutch Wadden Sea. Mar. Ecol. Prog. Ser. 101, 81-90.

van der Veer, H.W., Aliaume, C., Miller, J.M., Adriaans, E.J., Witte, J.IJ., Zerbi, A., 1994. Ecological observations on juvenile flatfish in a tropical coastal system, Puerto Rico. Neth. J. Sea Res. 32, 453-460.

van der Veer, H.W., Adriaans, E., Bolle, L.J., Dankers, N., Malaba da Fonseca, L., Walker, P.A., Witte, J.IJ., 1995. Ecological observations on juvenile flatfish in a tropical estuary: Arquipelago dos Bijagos, Guinea-Bissau. Neth. J. Sea Res. 34, 221-228.

van Duyl, F.C., 1985. Atlas of the living reefs of Bonaire and Curaçao (Netherlands Antilles). Natuurwetenschappelijke Studiekring voor Suriname en de Nederlandse Antillen 117. Weigt, L.A., Baldwin, C.C., Driskell, A., Smith, D.G., Ormos, A., Reyier, E.A., 2012. Using DNA Barcoding to assess Caribbean reef fish biodiversity: Expanding taxonomic and geographic coverage. PLoS ONE 7(7): e41059. doi:10.1371/journal.pone.0041059 
Wood, S.N., 2011. Fast stable restricted maximum likelihood and marginal likelihood estimation of semiparametric generalized linear models. J. Royal Stat. Soc. (B) 73, 3-36.

Zijlstra, J.J., 1972. On the importance of the Waddensea as a nursery area in relation to the conservation of the southern North Sea fishery resources. Symp. Zool. Soc. Lond. 29, 233-258.

Zijlstra, J.J., Dapper, R., Witte, J.IJ., 1982. Settlement, growth and mortality of post-larval plaice (Pleuronectes platessa) in the western Wadden Sea. Neth. J. Sea Res. 15, 250272.

Zuur, A.F., Ieno, E.N., Elphick, C.S., 2010. A protocol for data exploration to avoid common statistical problems. Meth. Ecol. Evol. 1, 3-14. 
Table 1 Von Bertalanffy parameters of the Bothus species at Curaçao, Linf, $\mathrm{K}$ and to with 95\% confidence intervals (between brackets; this study), together with number of samples (N)

\begin{tabular}{|l|c|c|c|c|}
\hline & $\mathrm{N}$ & $\operatorname{Linf}(\mathrm{cm})$ & $\mathrm{K}\left(\mathrm{y}^{-1}\right)$ & $\mathrm{t}_{0}(\mathrm{y})$ \\
\hline B ocellatus & 137 & $20.6(16.5-31.9)$ & $0.50(0.27-0.72)$ & $-0.06(-0.15-0.00)$ \\
\hline B. maculiferus & 112 & $50.5(36.3-94.5)$ & $0.82(0.36-1.36)$ & $0.16(0.11-0.20)$ \\
\hline B. Iunatus & 53 & $38.6(33.1-54.7)$ & $2.92(1.23-4.66)$ & $0.17(0.03-0.22)$ \\
\hline
\end{tabular}


Table 2. Comparison of length growth estimates $\left(\mathrm{cm} \mathrm{mo}^{-1}\right)$ for various temperate, subtropical and tropical juvenile flatfish species in size around $10 \mathrm{~cm}$ after correction for temperature differences by applying a $Q_{10}$ of 2 .

\begin{tabular}{|c|c|c|c|c|c|c|}
\hline $\begin{array}{l}\text { Species } \\
\text { type }\end{array}$ & Area & $\begin{array}{l}\text { Temperature } \\
\text { range }\left({ }^{\circ} \mathrm{C}\right)\end{array}$ & Species & $\begin{array}{c}\text { Growth } \\
(\mathrm{cm} \cdot \mathrm{mo}-1)\end{array}$ & $\begin{array}{c}\text { Growth } \\
\text { after Q10 } \\
\text { correction }\end{array}$ & Reference \\
\hline \multirow[t]{2}{*}{ Temperate } & $\begin{array}{l}\text { Wadden } \\
\text { Sea, NL }\end{array}$ & $4-20$ & Pleuronectes platessa & 1.5 & 1.5 & van der Veer et al., 1994 \\
\hline & & $4-18$ & Limanda limanda & 0.7 & 0.7 & van der Veer et al., 1994 \\
\hline \multirow[t]{2}{*}{ Subtropical } & $\begin{array}{l}\text { Georgia, } \\
\text { U.S.A. }\end{array}$ & $10-30$ & $\begin{array}{l}\text { Citharichthys } \\
\text { spilopterus }\end{array}$ & 1.6 & 1.1 & $\begin{array}{l}\text { Reichert \& van der Veer, } \\
1991\end{array}$ \\
\hline & & $10-30$ & Symphurus plagiusa & 1.2 & 0.8 & $\begin{array}{l}\text { Reichert \& van der Veer, } \\
1991\end{array}$ \\
\hline \multirow[t]{5}{*}{ Tropical } & $\begin{array}{l}\text { Gulf of } \\
\text { Mexico }\end{array}$ & \pm 27 & $\begin{array}{l}\text { Cyclopsetta } \\
\text { chittendeni }\end{array}$ & 2.3 & 1.0 & $\begin{array}{l}\text { Dawson, } 1968 \text { in Pauly, } \\
1994\end{array}$ \\
\hline & & \pm 27 & Citharichthys stampii & 3.4 & 1.4 & van der Veer et al., 1994 \\
\hline & Curaçao & \pm 27 & Bothus ocellatus & 0.7 & 0.3 & This study \\
\hline & & \pm 27 & Bothus maculiferus & 1.8 & 0.8 & This study \\
\hline & & \pm 27 & Bothus Iunatus & 4.3 & 1.8 & This study \\
\hline
\end{tabular}




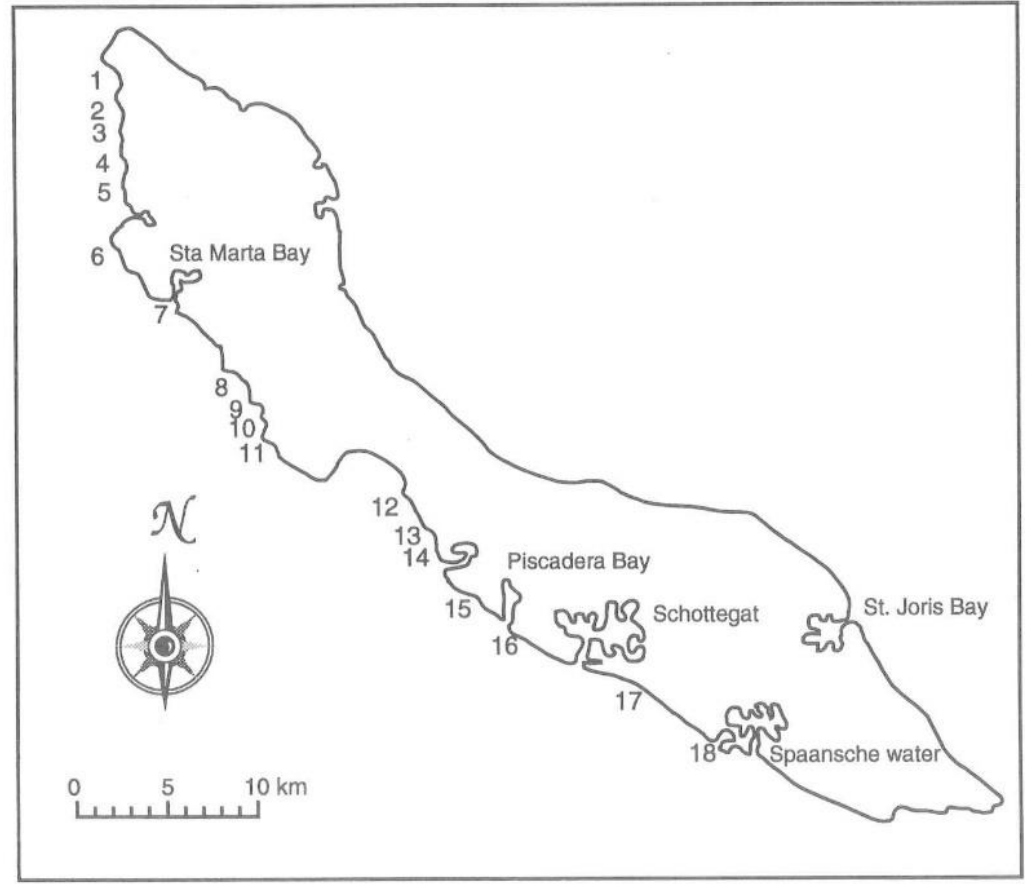

Figure 1 Map of Curaçao and the sampling stations. 1: Playa Kalki; 2: Grote Knip; 3: Kleine Knip; 4: Playa Jeremi; 5: Playa Legun; 6: Playa Manalina; 7: Coral cliff; 8: Cas Abao; 9: Porto Marie; 10: Daaibooibaai; 11: Rif St. Marie; 12: Pestbaai; 13: Varkensbaai; 14: Boca St. Michiel; 15: Blauwbaai; 16: Carmabi; 17: Sea aquarium/Jan Thiel; 18: Caracasbaai. 


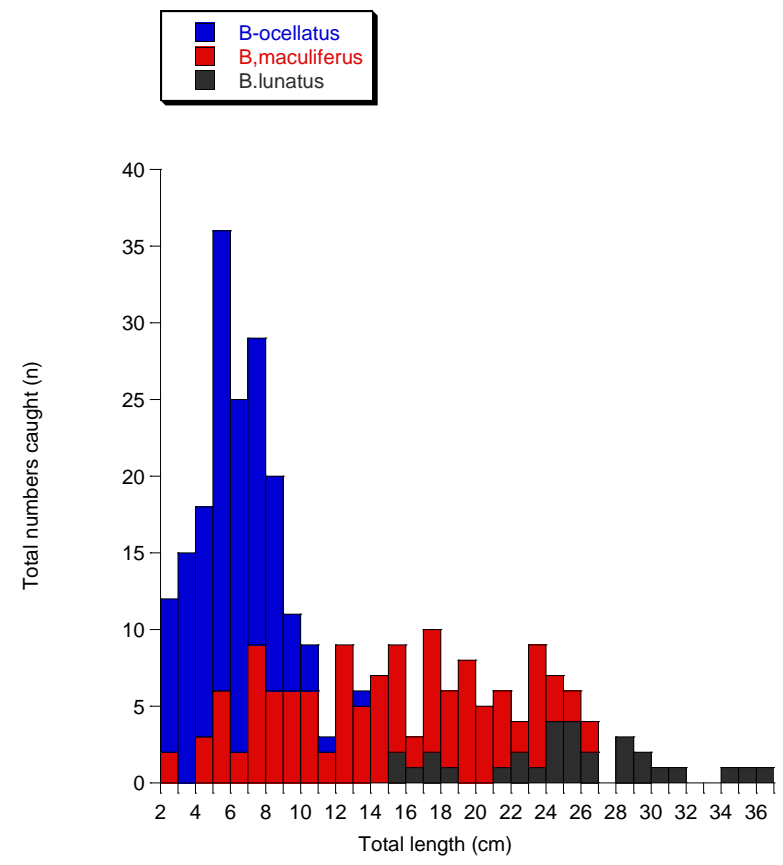

Figure 2. Size frequency distribution ( $n$ ) of the various flatfish species caught at Curaçao, all data combined.

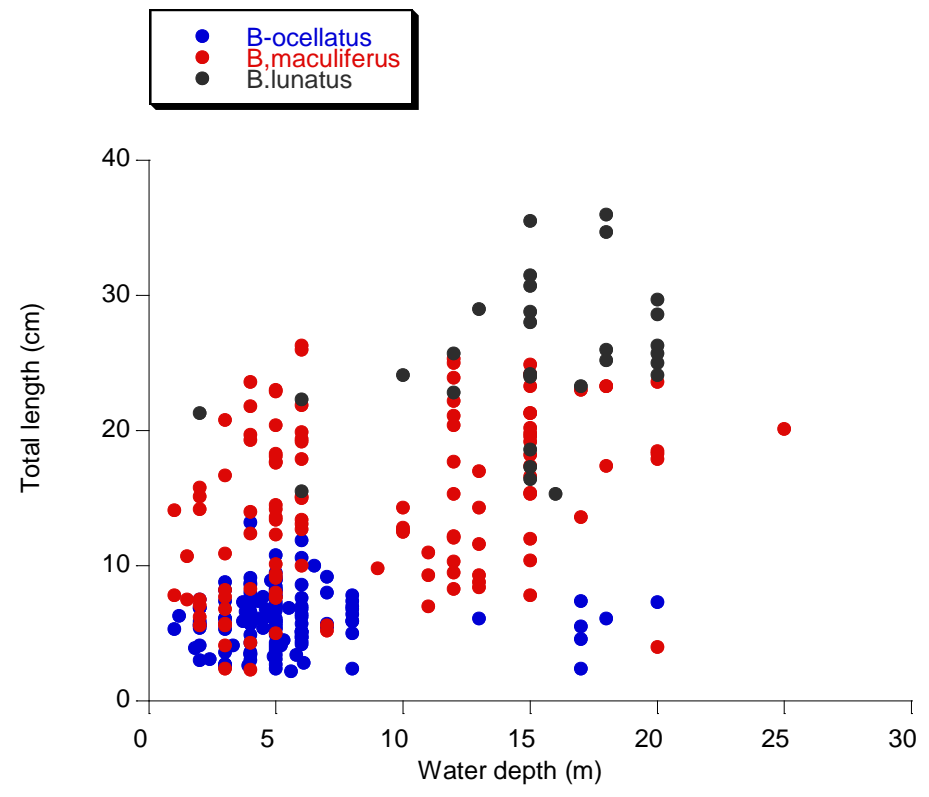

Figure 3. Relationship between water depth of capture $(\mathrm{m})$ and flatfish size $(\mathrm{cm})$ for the various flatfish species at Curaçao, all data combined. 

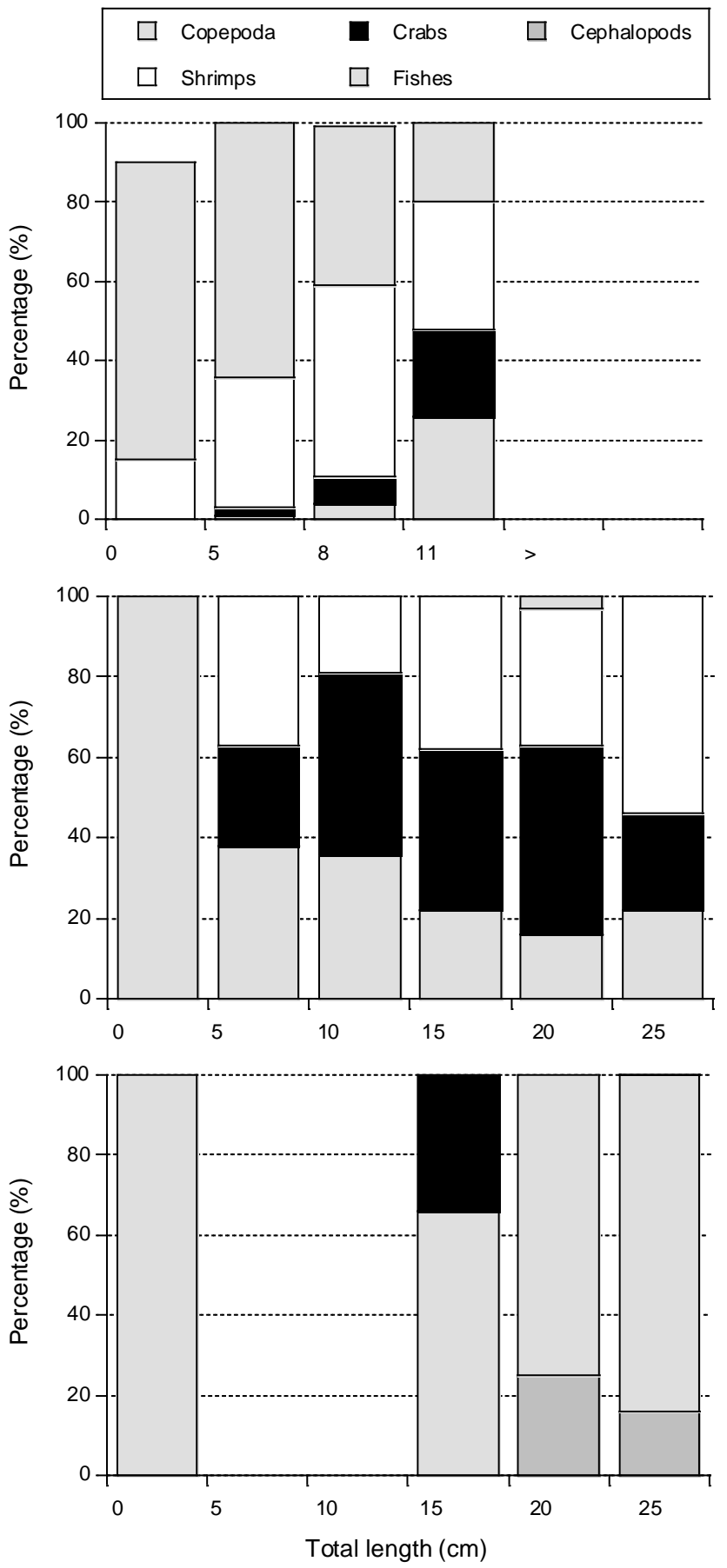

Figure 4. Percentage of different food types in the stomachs of Bothus ocellatus (top), $B$. maculifeus (middle) and $B$. lunatus (bottom) at different length classes at Curaçao in 1995. 

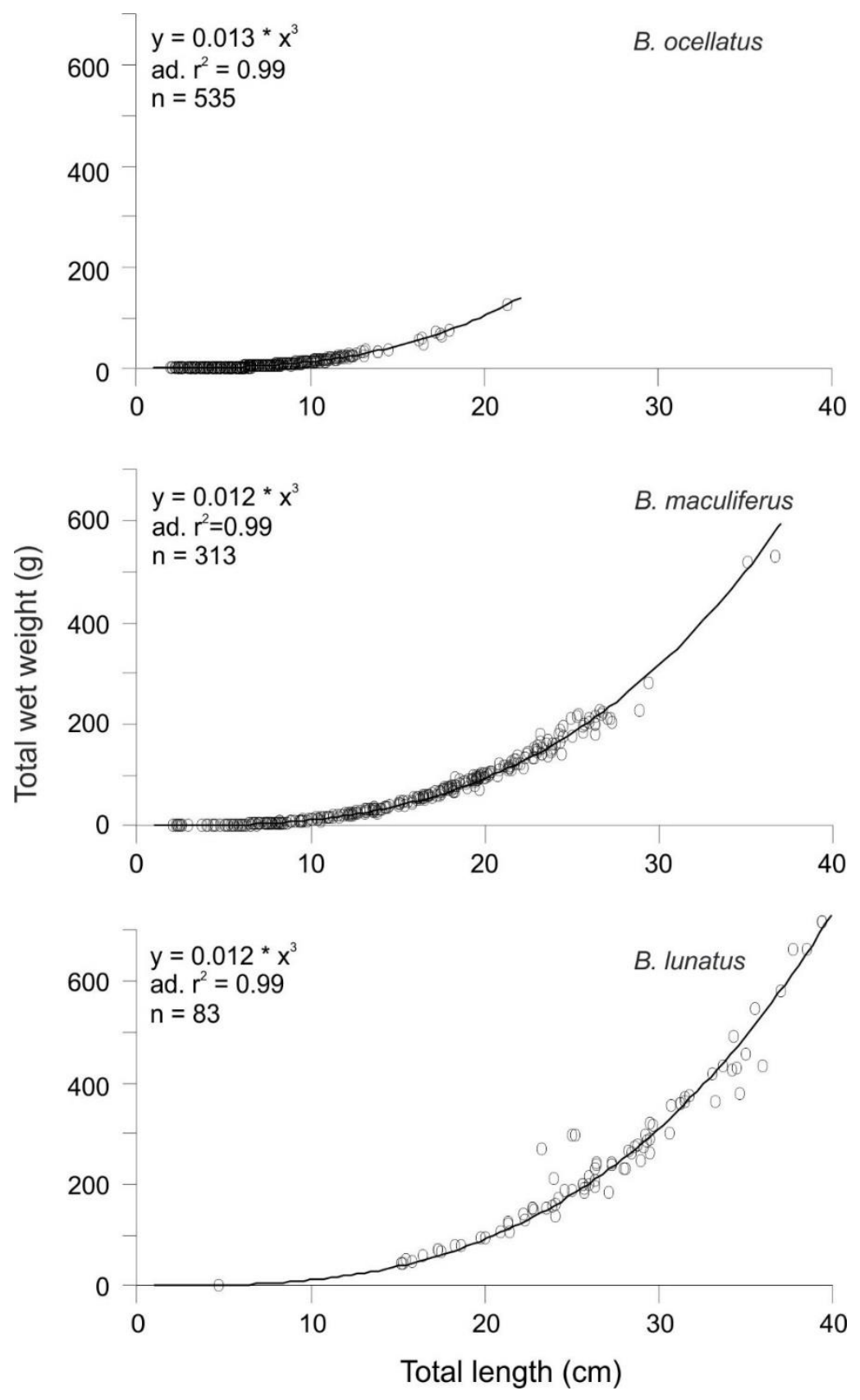

Figure 5. Total length $(\mathrm{cm})$ - wet weight $(\mathrm{g})$ relationships for $B$. ocellatus, B. maculiferus and $B$. lunatus at Curaçao in 1995. 


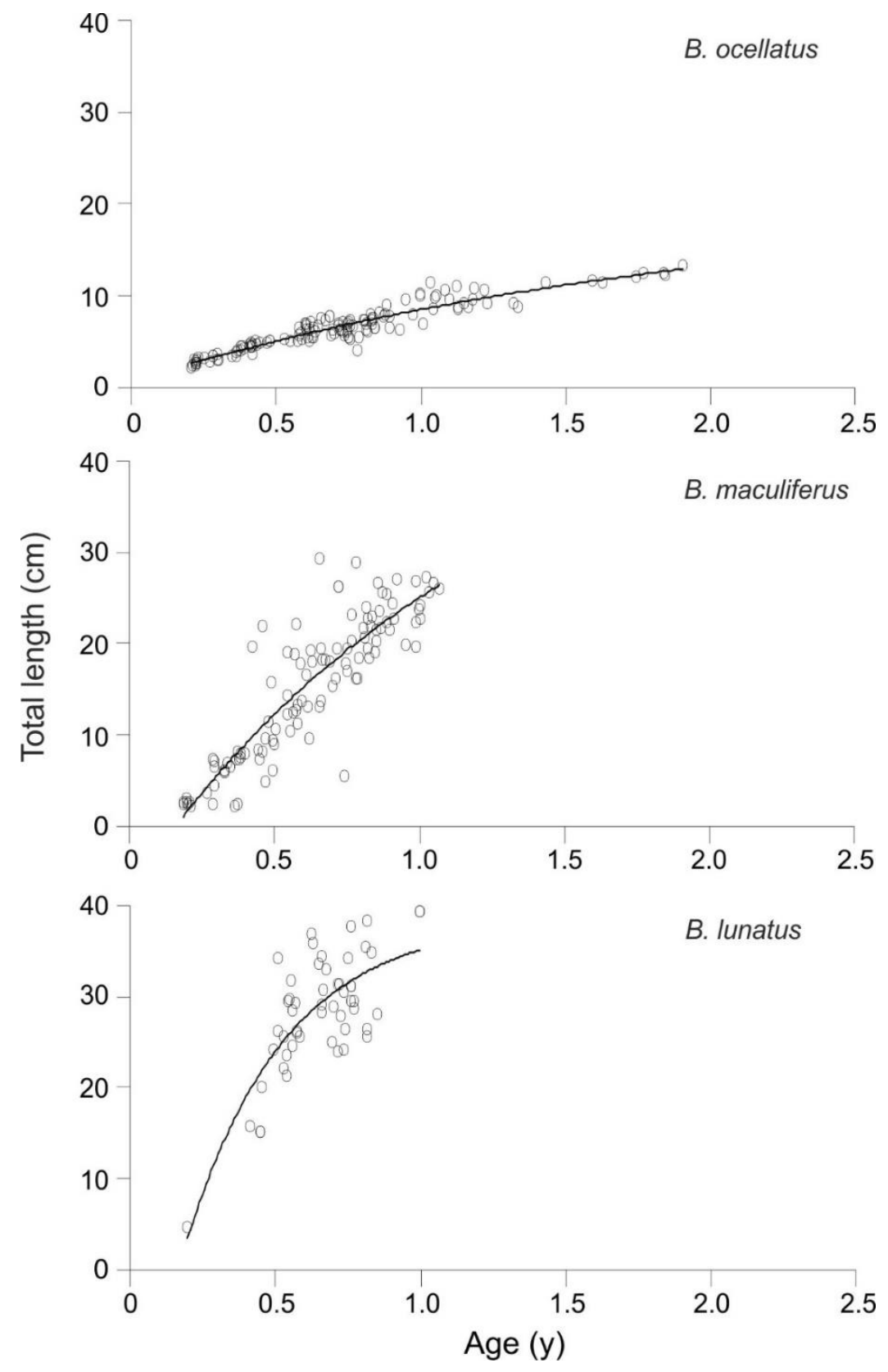

Figure 6. Von Bertalanffy growth curves for Bothus ocellatus (top), B. maculiferus (middle) and $B$. lunatus (bottom). For parameter, values see Table 1. 


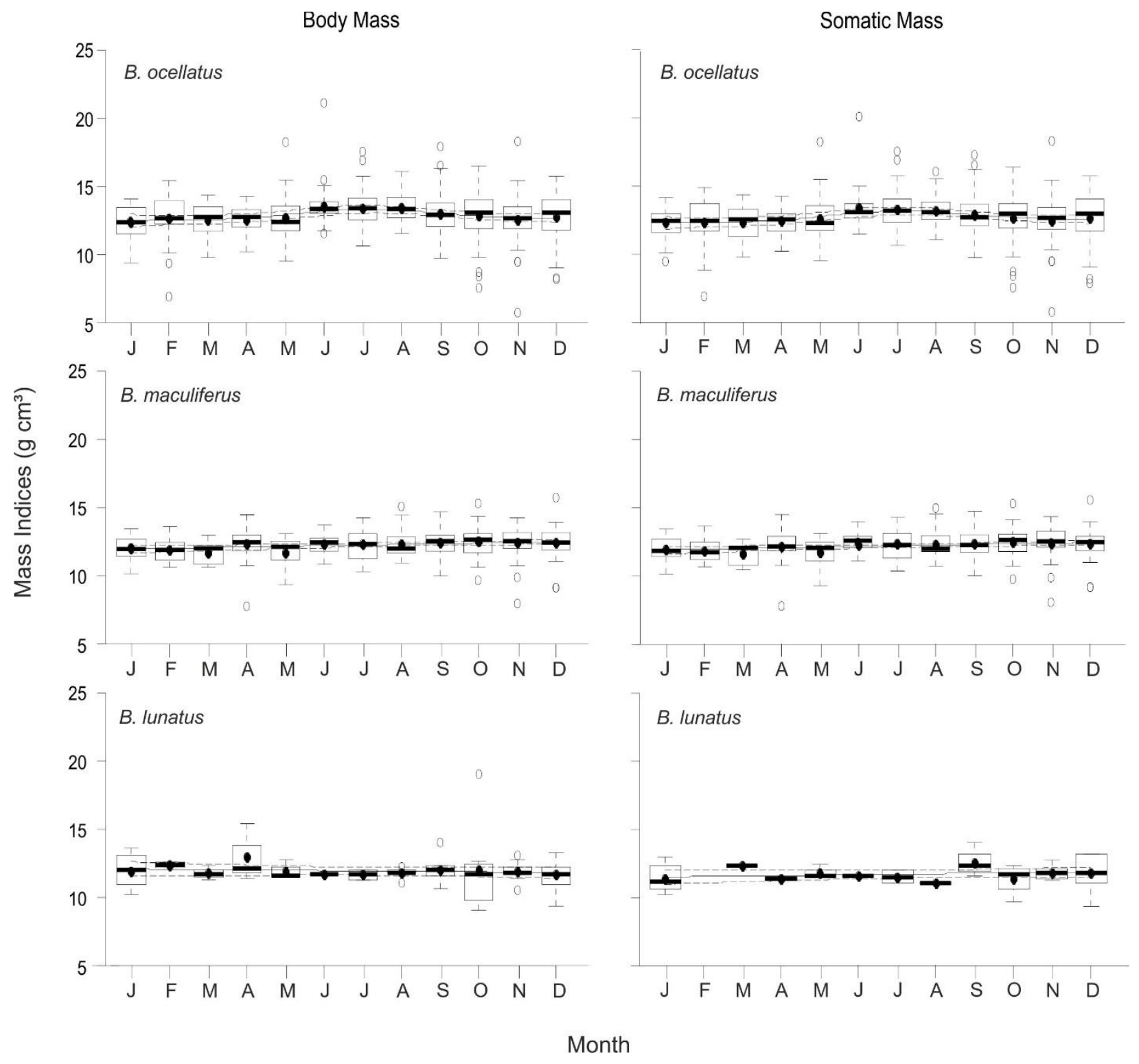

Figure 7. Seasonal pattern in body mass index (BMI; $\mathrm{g} \mathrm{cm}^{3}$ ) and somatic mass index (SMI; $\mathrm{g}$ $\mathrm{cm}^{3}$ ) for $B$. ocellatus, $B$. maculiferus and $B$. lunatus, for both sexes and years combined. Curves are GAM model predictions and dotted lines represent the $95 \%$ confidence intervals. Boxplots: full dots and horizontal bars indicate mean and median values; boxes represent the range within which the central $50 \%$ of the values fall; bars represent the data range excluding outliers; outliers are observations more 1.5 times the box range and are represented by open circles. 


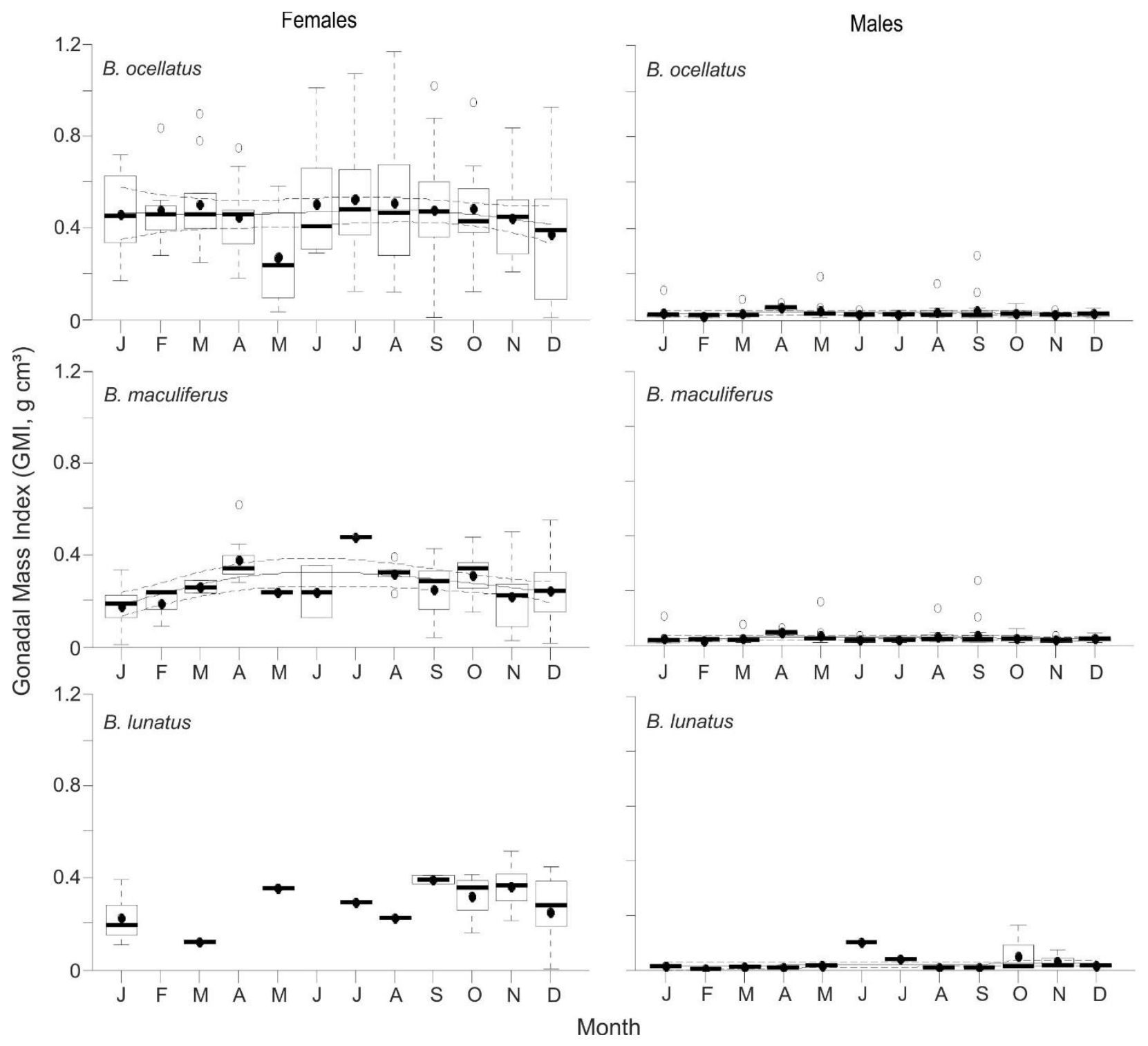

Figure 8. Seasonal pattern in gonadal mass index (GMI; $\mathrm{g} \mathrm{cm}^{3}$ ) for $B$. ocellatus, $B$. maculiferus and $B$. lunatus, for both years combined. Note that GMI values in plots are not sqrttransformed. Curves are GAM model predictions and dotted lines represent the $95 \%$ confidence intervals. Boxplots: full dots and horizontal bars indicate mean and median values; boxes represent the range within which the central $50 \%$ of the values fall; bars represent the data range excluding outliers; outliers are observations more 1.5 times the box range and are represented by open circles. Due to the low number of observations for female B. lunatus, no GAM curve could be predicted. 


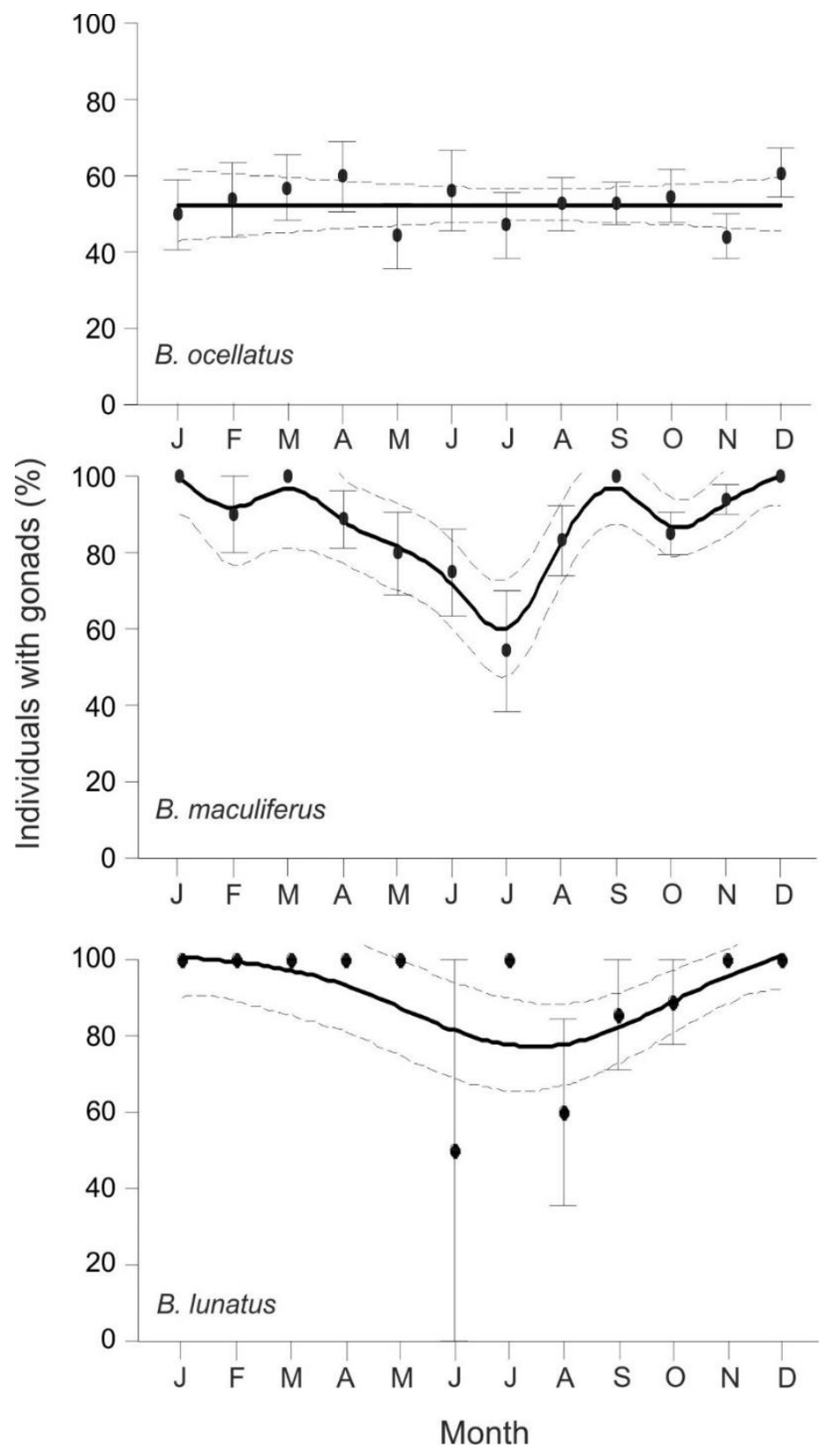

Figure 9. Proportion of flatfishes with gonads present $(>0.01 \mathrm{~g})$ along the year in $B$. ocellatus, B. maculiferus and B. lunatus, for both sexes and years combined. Curves are GAM model predictions and dotted lines represent the $95 \%$ confidence intervals. Full dots indicate mean values and bars represent the data range. 